\title{
ANALISIS PERSEBARAN EKOSISTEM HUTAN MANGROVE MENGGUNAKAN CITRA LANDSAT-8 DI ESTUARI PERANCAK BALI
}

\author{
ANALYSIS OF THE DISTRIBUTION OF MANGROVE FOREST ECOSYSTEMS USING LANDSAT - 8 IN ESTUARINE \\ PERANCAK BALI
}

\author{
Afrinda Dara Kartikasari ${ }^{1}$, Bangun Muljo Sukojo ${ }^{1}$ \\ ${ }^{1} J u r u s a n$ Teknik Geomatika FTSP-ITS, Kampus ITS Sukolilo, Surabaya, 60111
}

Email: bangunms@gmail.com

\begin{abstract}
Abstrak
Mangrove adalah tanaman pepohonan atau komunitas tanaman yang hidup di antara laut dan daratan yang dipengaruhi oleh pasang surut. Ekosistem mangrove banyak ditemukan di pantai-pantai teluk yang dangkal, estuaria, delta dan daerah pantai yang terlindung (Bengen, 2001). Kawasan Estuari Perancak memiliki luasan cukup besar dengan penggunaan lahan berupa tambak dan hutan mangrove. Wilayah perancak memiliki karakteristik yang khas. Sebagai sebuah estuari yang kondisi badan airnya dipengaruhi oleh asupan air asin dari Selat Bali dan air tawar dari sungai yang bermuara didalamnya. Dengan mengintegrasikan teknologi penginderaan jauh menggunakan citra satelit Landsat-8 diharapkan mampu mempermudah dalam mengkaji pemetaan mangrove. Algoritma yang digunakan adalah NDVI digunakan untuk menggambarkan tingkat kehijauan suatu jenis mangrove. Penentuan jenis mangrove dilakukan menggunakan metode transek $10 \times 10 \mathrm{~m}$ dengan kegiatan menghitung jenis mangrove, mengukur diameter dan tinggi pohon dan mengambil gambar kanopi pohon mangrove. Untuk pengambilan sampel air dilakukan di 13 titik pada saat kondisi air laut pasang. Berdasarkan hasil penelitian, didapatkan luas hutan mangrove di Estuari perancak pada tahun 2015 sebesar $651200 \mathrm{~m}^{2}$. Korelasi parameter fisik hidrologi (salinitas, TSS) dengan persebaran hutan mangrove berdasarkan nilai NDVI didapatkan nilai korelasi berturut-turut adalah 0.7658 , dan 0.2902 yang artinya korelasi antara NDVI dengan salinitas kuat, korelasi antara NDVI dengan TSS sangat rendah. Sehingga jika nilai NDVI tinggi tidak pasti nilai TSS tinggi pula, hal ini dikarenakan letak penelitian yang dikelilingi oleh sungai dan jarak dari bibir pantai sepanjang $3133.45 \mathrm{~m}$.
\end{abstract}

Kata Kunci: Mangrove, Penginderaan Jauh, NDVI, Korelasi.

\begin{abstract}
Abstract-Mangrove trees are plants or plant communities that live that lives in intertidal zone that is affected by the tides. Mangrove ecosystems are found on the shores of shallow bays, estuaries, deltas and coastal areas are protected (Bengen, 2001). Perancak Estuary region has an area large enough to land use in the form of ponds and mangrove forests. Perancak region has distinctive characteristics. As a condition estuary water bodies affected by the intake of salty water from Bali Strait and fresh water from a river that flows therein. By integrating remote sensing technology using satellite images Landsat 8 is expected to ease in reviewing the mangrove mapping. The algorithm used is NDVI is used to describe a type of mangrove greenness level. psiognomic mangrove measurement was done by using transect method $10 \times 10 \mathrm{~m}$ with counting activities mangrove species, measure the diameter and height of trees and taking pictures canopy of mangrove trees. For water sampling conducted at 13 points at the time of high tides condition. Based on the research results, obtained extensive mangrove forests in Perancak Estuary in 2015 amounted to $651200 \mathrm{~m}^{2}$. Correlation of the physical parameters of hydrology (salinity, TSS) with a spread of mangrove forests based NDVI values obtained correlation values are respectively 0.7658 , and 0.2902 , which means the correlation between NDVI with strong salinity, the correlation between NDVI with very low TSS. So if high NDVI values uncertain TSS higher the value, this is due to the location of the research which is surrounded by the river and the distance from the shoreline along $3133.45 \mathrm{~m}$.
\end{abstract}

Keywords: Mangrove, Remote Sensing, NDVI, Correlation. 


\section{PENDAHULUAN}

\section{Latar Belakang}

Ekosistem mangrove merupakan ekosistem yang kompleks terdiri atas flora dan fauna daerah pantai. Selain menyediakan keanekaragaman hayati (biodiversity), ekosistem mangrove juga sebagai plasma nutfah (genetic pool) dan menunjang keseluruhan sistem kehidupan di sekitarnya.

Seiring dengan pertumbuhan penduduk yang semakin cepat, maka kebutuhan hidup manusia akan semakin meningkat. Dengan meningkatnya kebutuhan ini akan menimbulkan tekanan terhadap sumberdaya alam, dimana pemanfaatan belum banyak memperhitungkan kerugian yang berdampak ekologis. Demikian juga dengan pembangunan wilayah pesisir sekitar kawasan hutan mangrove, pemanfaatan wilayahnya biasanya tidak dilakukan dengan bijaksana dan berwawasan lingkungan.

Kawasan Estuari Perancak memiliki luasan cukup besar dengan penggunaan lahan berupa tambak dan hutan mangrove. Total luas di estuari ini sekitar 876 ha dengan lebih dari 390 ha merupakan lahan tambak, baik yang masih aktif maupun yang sudah tidak aktif, serta 78,6 ha merupakan hutan mangrove (Balai Riset dan Observasi Kelautan, 2004).

Citra yang digunakan dalam penelitian ini adalah Landsat 8 tahun 2015. Landsat 8 memiliki kemampuan untuk merekam citra dengan resolusi 3 meter, serta dilengkapi oleh 11 kanal yang dapat mempermudah proses interpretasi persebaran mangrove di wilayah Estuari Perancak. Hutan mangrove hidup diwilayah pesisir laut dan sungai sehingga indeks vegetasi yang digunakan adalah NDVI yang menggambarkan tingkat kehijauan suatu jenis mangrove.

Manfaat yang ingin diperoleh dari penelitian ini adalah mampu mengetahui penyebaran mangrove di wilayah Estuari Perancak, mengetahui hidrologi Estuari Perancak yang dilihat dari parameter fisik (pasang surut, salinitas dan sedimentasi), dan hubungan antara persebaran hutan mangrove dengan parameter hidrologi. Selain itu, hasil dari penelitian ini juga diharapkan dapat dimanfaatkan untuk pengambilan kebijakan dalam pengembangan mangrove di Estuari Perancak, Bali.

\section{METODOLOGI PENELITIAN}

\section{Data Dan Peralatan}

\section{- Data}

Data yang digunakan dalam penelitian ini adalah:

1. Citra satelit Landsat-8

2. Peta rupa bumi Delodbaleagung dan Munduk skala 1:25000.

3. Data Pasang Surut tahun 2015

4. Data lapangan hasil ground control dan ground truth

\section{- Peralatan}

Peralatan yang digunakan dalam penelitian ini adalah:
1. Laptop
2. Kamera Digital
3. GPS Handheld
4. Perangkat lunak pengolah citra

\section{Metode Penelitian}

Penelitian ini dilakukan di wilayah Estuari Perancak yang terletak antara $8^{\circ} 22^{\prime} 30^{\prime \prime}$ LS sampai $8^{\circ} 24^{\prime} 18^{\prime \prime} \mathrm{LS}$ dan $114^{\circ} 36^{\prime} 18^{\prime \prime}$ BT sampai $114^{\circ} 38^{\prime} 31,2^{\prime \prime}$ BT. Berikut merupakan gambar dari lokasi penelitian:

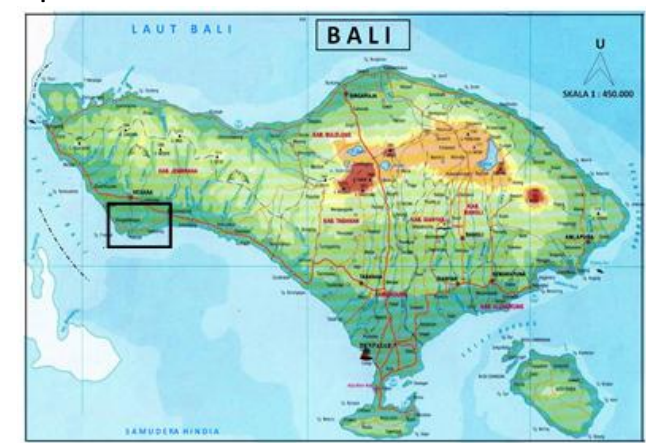

Gambar. 1. Lokasi Penelitian Estuari Perancak (sumber: Nandi, 2011)

Secara garis besar tahapan dari penelitian yang dilakukan terdiri dari 5 tahapan yaitu tahap persiapan yaitu identifikasi masalah, studi literatur dan pengumpulan data, tahap pengolahan data, tahap analisa dan tahap akhir berupa penyusunan laporan.

Proses pengolahan data yang dilakukan tertuang pada diagram alir pengolahan data berikut: 


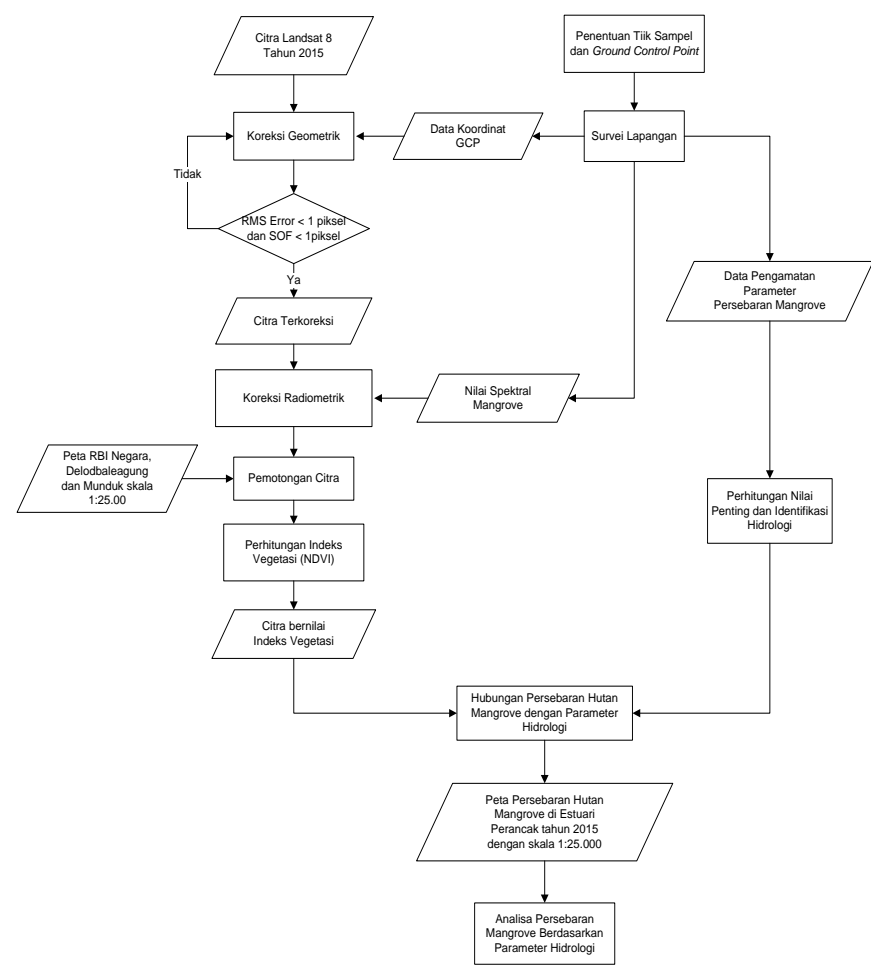

Gambar 2. Diagram Alir Pengolahan Data

Penjelasan dari diagram alir pengolahan data adalah sebagai berikut:

a. Pembetulan citra secara geometrik sehingga proyeksi peta dan sistem koordinat yang digunakan sesuai dengan dunia nyata. Koreksi Geometrik pada citra dengan bantuan pengambilan titik Ground Control Point (GCP) dilapangan menggunakan GPS handheld untuk citra Landsat 8. Titik - titik GCP lebih dari 4 buah agar nilai RMS Error yang di dapatkan kurang dari 1 piksel. Apabila nilai RMS Error masih melebihi nilai 1 piksel maka harus dilakukan koreksi geometrik ulang, sehingga akan didapatkan citra yang bergeoreferensi. Dalam melakukan koreksi geometrik citra tersebut hasil dari perhitungan SOF (Strenght of Figure) harus mendekati nol (SOF $\approx 0$ ) dan Root Mean Square Errors (RMSE) harus lebih kecil dari 1 pixel (RMSE < 1 pixel).

]

b. Koreksi Radiometrik untuk memperbaiki nilai piksel agar sesuai dengan yang seharusnya yang biasanya mempertimbangkan faktor gangguan atmosfer sebagai sumber kesalahan utama (Soenarmo, 2009). Koreksi radiometrik pada kedua citra dengan bantuan nilai digital number mangrove yang diambil di lapangan menggunakan kamera.

c. Data citra Landsat 8 tahun 2015 dilakukan cropping sesuai dengan batasan administrasi Estuari Perancak.

d. Melakukan pengolahan indeks vegetasi NDVI dengan cara memasukkan algoritma indeks vegetasi. Kemudian melakukan pengelompokan indeks vegetasi sesuai dengan nilai NDVI titik - titik di lapangan.

e. Ground truth ini dilakukan untuk pengambilan koordinat GCP dilapangan, pengambilan sampel untuk mengetahui nilai parameter hidrologi dan unsur ekosistem mangrove dan pengambilan gambar hutan mangrove untuk mengetahui nilai digital number hutan mangrove dan kemudian dicocokkan dengan nilai pada citra.

f. Perhitungan nilai penting data transek $10 \mathrm{x}$ $10 \mathrm{~m}$ dan identifikasi parameter hidrologi.

g. Membuat korelasi persebaran hutan mangrove dengan parameter hidrologi menggunakan regresi linier kuadratik antara nilai penting dengan NDVI dan NDVI dengan salinitas dan TSS.

h. Membuatan layout peta sesuai dengan kaidah kartografi. Kemudian didapatkan peta persebaran hutan mangrove tahun 2015 dengan skala 1:25000.

i. Analisa persebaran mangrove dilihat dari hidrologi berdasarkan parameter fisik (pasang surut, salinitas dan sedimentasi).

\section{HASIL DAN PEMBAHASAN}

\section{Koreksi}

Transverse Mercator (UTM) zona $50 \mathrm{~S}$, dengan datum World Geodetic System (WGS) 1984. Ground Control Point (GCP) dipilih pada daerah persimpangan jalan dan pecabangan sungai. Hal ini dilakukan karena daerah tersebut lebih mudah untuk diidentifikasi. Dari hasil pelaksanaan koreksi geometrik citra satelit tahun Landsat 8 tahun 2015 menggunakan 13 titik GCP, nilai kesalahan Root Mean Square (RMS) adalah 0.304967 piksel. Sehingga hal ini telah masuk toleransi yang disyaratkan yaitu kurang dari 1 piksel (Purwadhi, 2001). 


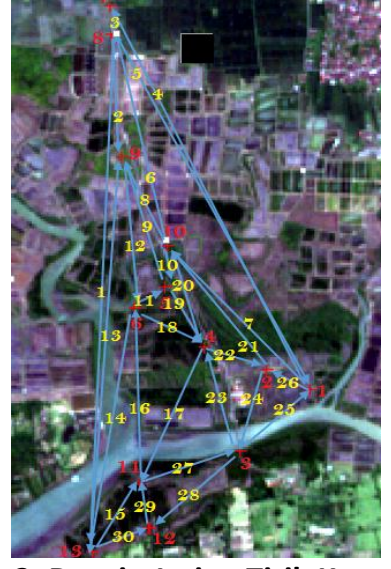

Gambar 3. Desain Jaring Titik Kontrol Citra

Desain jaring titik-titik GCP diatas kemudian dilakukan perhitungan Srenght of Figure (SoF) sebagai berikut:

Jumlah baseline : 30

Jumlah titik : 13

N_ukuran : Jumlah baseline $\times 3=900$

N_parameter : Jumlah titik $\times 3=39$

$\mathrm{U} \quad$ : N_ukuran $-\mathrm{N} \_$parameter $=51$

Strength of Figure $=\left[\operatorname{Trace}\left(A^{\top} A\right)^{-1}\right] / \mathrm{U}$

$=0.0641$

Dari hasil perhitungan nilai kekuatan jaring adalah 0,0641 . Dimana semakin kecil bilangan faktor kekuatan jaringan tersebut di atas, maka akan semakin baik konfigurasi jaringan dan sebaliknya (Abidin, 2002).

Nilai SoF yang dihasilkan jaring diatas telah masuk toleransi yang disyaratkan yaitu kurang dari 1 , sehingga desain jaring SoF dianggap kuat.

\section{Koreksi Radiometrik}

Tujuan utama dari kalibrasi radiometrik ini adalah untuk mengubah data pada citra yang pada umumnya) disimpan dalam bentuk Digital Number (DN) menjadi reflectance. Adapun rumus konversi DN ke reflektan adalah sebagai berikut (USGS, 2013):

$$
\rho \lambda^{\prime}=\text { MpQcal + Ap }
$$

dimana:

$\rho \lambda^{\prime}=$ Nilai reflektan, tanpa koreksi sudut matahari

$\mathrm{M} \rho=$ Faktor multiplicative rescaling setiap band dari metadata

(REFLECTANCE_MULT_BAND_x, dimana $x$ adalah nomer band)

$A \rho=$ Faktor additive rescaling setiap band dari metadata

(REFLECTANCE_ADD_BAND_x, dimana $x$ adalah nomer band)

\section{Qcal = Nilai Digital Number band}

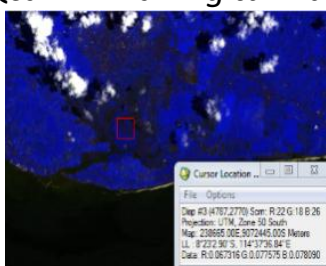

(a)

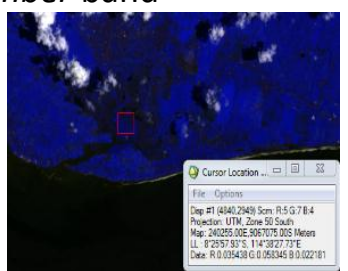

(b)
Gambar 4. (a) Citra sebelum dikonversi, terlihat masih dalam nilai digital number (b) Citra setelah dikonversi, telah berubah dalam nilai reflektan

\section{Penentuan Jenis Mangrove}

Penelitian ini menggunakan transek yang berukuran $10 \times 10 \mathrm{~m}$ sebanyak 13 buah yang dilakukan pada tanggal 27-28 Februari 2015, pada bulan ini musim penghujan. Transek ini digunakan untuk menentukan jenis mangrove yang dominan dalam satu area.

Dalam satu transek dihitung jumlah pohon per spesies, diameter pohon setinggi orang dewasa dan tinggi pohon. Dari data transek kemudian dihitung nilai basal area tiap jenis, kerapatan relatif, penutup relatif, frekuensi relatif, dan nilai penting dalam satu area transek $10 \times 10 \mathrm{~m}$ tersebut.

Semakin tinggi nilai penting suatu spesies, maka semakin besar tingkat penguasaan spesies tersebut pada daerah tertentu. Besar kecilnya nilai penting dipengaruhi oleh jumlah individu yang ditemukan, besar pohon dan ketebalan hutan mangrove.

Pengambilan sampel air dilakukan pada tanggal 2 Maret 2015 pukul 10.00 - 11.45 WITA pada saat air laut pasang dengan tujuan sampel yang diambil benar-benar di lokasi transek. Pengambilan sampel air untuk mengetahui nilai salinitas dan TSS. Semua parameter diukur, dihitung dan dianalisa di Laboratorium Kualitas Perairan, Bali

\section{Peta Persebaran Hutan Mangrove}

Mangrove yang tumbuh diwilayah estuari sangat berbeda dengan mangrove yang tumbuh didekat pantai, mangrove estuari memiliki keunikan tersendiri, terbukti di wilayah Estuari Perancak ini mangrove tumbuh secara bercampur yang mana 
Tabel 1. Hasil Perhitungan untuk Menentukan Jenis Mangrove Dominan

\begin{tabular}{|c|c|c|c|c|c|c|}
\hline Titik & $\begin{array}{c}\text { Jenis } \\
\text { mangrove } \\
\text { dominan }\end{array}$ & $\begin{array}{c}\text { Jenis } \\
\text { mangrove } \\
\text { yang } \\
\text { ditemukan }\end{array}$ & $\begin{array}{l}\text { Kerapatan } \\
\text { Relatif } \\
\text { Spesies (\%) }\end{array}$ & $\begin{array}{l}\text { Penutup } \\
\text { Relatif } \\
\text { Spesies } \\
(\%)\end{array}$ & $\begin{array}{l}\text { Frekuensi } \\
\text { Relatif } \\
\text { Area per } \\
\text { Spesies } \\
(\%)\end{array}$ & $\begin{array}{c}\text { Nilai } \\
\text { Penting } \\
\text { Speies } \\
(\%)\end{array}$ \\
\hline \multirow[t]{2}{*}{1} & Rhizophora & Rhizophora & 94 & 67.744 & 93.506 & 254.757 \\
\hline & & Avicennia & 6 & 32.256 & 6.494 & 45.243 \\
\hline \multirow[t]{2}{*}{2} & Avicennia & Avicennia & 64 & 99.519 & 63.636 & 227 \\
\hline & & Rhizophora & 36 & 0.48 & 36.364 & 73.208 \\
\hline \multirow[t]{5}{*}{3} & Sonneratia & Bruguiera & 49 & 2.071 & 48.979 & 100.031 \\
\hline & & Rhizophora & 4 & 0.012 & 3.947 & 8 \\
\hline & & Avicennia & 26 & 33.576 & 26.316 & 86 \\
\hline & & Sonneratia & 5 & 63.019 & 5.263 & 74 \\
\hline & & Xylocarpus & 1 & 0.091 & 1.316 & 3 \\
\hline \multirow[t]{3}{*}{4} & Rhizophora & Rhizophora & 88 & 12.254 & 88.095 & 188 \\
\hline & & Sonneratia & 5 & 52.606 & 4.762 & 62 \\
\hline & & Avicennia & 7 & 35.139 & 7.143 & 49 \\
\hline \multirow[t]{2}{*}{5} & Rhizophora & Rhizophora & 7 & 52.309 & 7.143 & 67 \\
\hline & & Avicennia & 23 & 47.691 & 23.077 & 94 \\
\hline 6 & Rhizophora & Rhizophora & 100 & 100 & 100 & 300 \\
\hline \multirow[t]{2}{*}{7} & Bruguiera & Bruguiera & 45 & 99.235 & 45.455 & 190 \\
\hline & & Acanthus & 55 & 0.765 & 54.545 & 110 \\
\hline 8 & Acrostichum & Acrostichum & 100 & 100 & 100 & 300 \\
\hline 9 & Nypa & Nypa & 100 & 100 & 100 & 300 \\
\hline \multirow[t]{3}{*}{10} & Bruguiera & Avicennia & 2 & 73.159 & 1.852 & 77 \\
\hline & & Bruguiera & 67 & 18.149 & 66.667 & 151 \\
\hline & & Rhizophora & 31 & 8.691 & 31.481 & 72 \\
\hline 11 & Rhizophora & Rhizophora & 100 & 100 & 100 & 300 \\
\hline 12 & Rhizophora & Rhizophora & 100 & 100 & 100 & 300 \\
\hline 13 & Rhizophora & Rhizophora & 100 & 100 & 100 & 300 \\
\hline
\end{tabular}

dalam satu lokasi terdapat 2 sampai 4 jenis yang berbeda. Jenis mangrove yang paling banyak ditemukan adalah Rhizophora $s p$ dan spesies yang paling sedikit adalah Avicennia $s p$.

Hutan mangrove di wilayah Estuari Perancak menyebar secara rata dan jenis mangrove yang mendominasi adalah spesies Rhizophora.

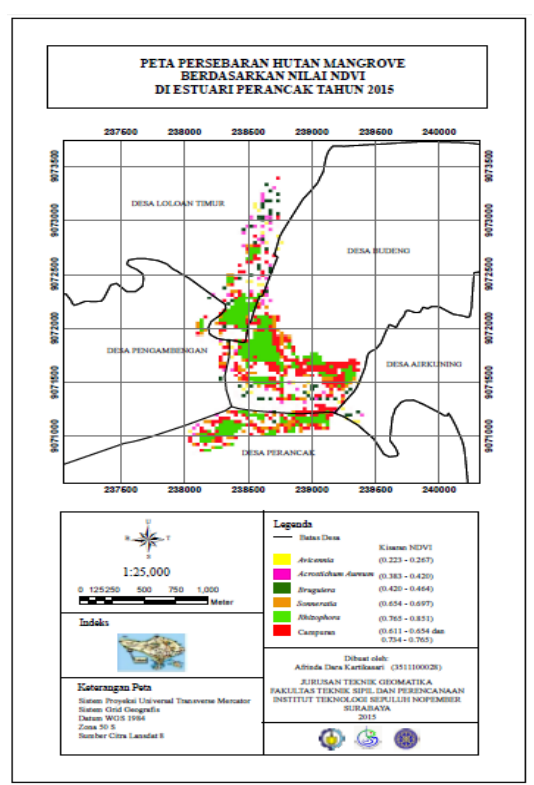

Gambar 5. Persebaran Hutan Mangrove tahun 2015

\section{Luas Hutan Mangrove}

Dari hasil klasifikasi hutan mangrove dan hasil perhitungan jenis mangrove dominan di wilayah Estuari perancak tahun 2015 diperoleh luasan sebagai berikut:

Tabel 2. Luas Hutan Mangrove tahun 2015

\begin{tabular}{cc}
\hline Jenis Mangrove & Luas 2015 \\
\hline Rhizophora apiculata & 257400 \\
\hline Avicennia alba & 18000 \\
\hline Sonneratia alba & 70200 \\
\hline Bruguiera $s p$ & 38700 \\
\hline Acrostichum $s p$ & 4100 \\
\hline Campuran & 262800 \\
\hline Total & 651200 \\
\hline
\end{tabular}

\section{Analisa Vegetasi}

Dari hasil transek $10 \times 10 \mathrm{~m}$ di Estuari Perancak terdapat 7 jenis mangrove, yaitu Avicennia, Sonneratia, Bruguiera, Rhizophora, Nypa, Acrostichum aureum, Acanthus dengan luas hutan mangrove sebesar $110.500 \mathrm{~m}^{2}$.

\section{Analisa Pola Hidrologi}

Wilayah perancak memiliki karakteristik yang khas. Sebagai sebuah estuari yang kondisi badan airnya dipengaruhi oleh asupan air asin dari Selat 
Bali dan air tawar dari sungai yang bermuara didalamnya, Estuari Perancak berfluktuasi sesuai dengan kondisi kedua sumber asupan tersebut. Sumber asupan air tawar utama berasal dari 3 sungai utama yaitu Sungai ljo Gading, Sungai Samblong, dan Sungai Yeh Kuning.

Hutan bakau di wilayah Estuari Perancak tumbuh di atas lumpur tanah liat bercampur dengan bahan organik. Pada wilayh ini tidak ada substrat lumpur yang mengandung pasir atau pecahan karang karena lokasi penelitian bukan di dekat pantai-pantai tetapi di wilayah estuari yang dikelilingi oleh sungai - sungai.

Wilayah Estuari perancak bertipe pasang surut campuran condong ke harian ganda (mixed tide prevailing semidiurnal) yang artinya dalam satu hari terjadi satu kali air pasang dan satu kali air surut, tetapi kadang-kadang untuk sementara waktu terjadi dua kali pasang dan dua kali surut dengan tinggi dan periode yang sangat berbeda. Pasang surut jenis ini juga terjadi di Selat Kalimantan dan Pantai Utara Jawa Barat.

Tinggi muka air laut (MSL) di Pelabuhan Perikanan Pengambengan, Bali sebesar $141,8 \mathrm{~cm}$ (Latifah, 2008). Mangrove tergenang dua kali dalam 1 hari dengan lama genangan 1 sampai 2 jam dilihat dari data pasang surut pengambengan.

Tingkat sedimentasi di Estuari Perancak cukup tinggi, hal ini terlihat dari banyaknya komunitas mangrove yang mulai tumbuh di daerah hasil sedimen sehingga terlihat seperti ada pulau baru di wilayah tersebut, hal ini dapat diperjelas dengan hasil laboratoriun TSS di Estuari Perancak tabel 3.

Tabel 3. Data TSS Hasil Penelitian di Estuari Perancak pada saat pasang dibandingkan terhadap Baku Mutu untuk Biota Laut

\begin{tabular}{ccccccc}
\hline $\begin{array}{c}\text { Nama } \\
\text { Titik }\end{array}$ & Koordinat & Y & $\begin{array}{c}\text { Jenis } \\
\text { mangrove } \\
\text { dominan }\end{array}$ & $\begin{array}{c}\text { TSS } \\
(\mathrm{mg} / \mathrm{L})\end{array}$ & $\begin{array}{c}\text { Baku } \\
\text { Mutu }\end{array}$ & Ket \\
\hline 1 & 239135.65 & 9071372.67 & Rhizophora & 29 & 80 & Ya \\
\hline 2 & 238975.57 & 9071498.66 & Avicennia & 8 & 80 & Ya \\
\hline 3 & 238808.59 & 9071165.75 & Sonneratia & 15 & 80 & Ya \\
\hline 4 & 238761.58 & 9071640.29 & Rhizophora & 18 & 80 & Ya \\
\hline 5 & 238650.19 & 9071927.58 & Rhizophora & 20 & 80 & Ya \\
\hline 6 & 238510.37 & 9071864.08 & Rhizophora & 195 & 80 & Tidak \\
\hline 7 & 238678.34 & 9073170.63 & Bruguiera & 11 & 80 & Ya \\
\hline 8 & 238664.67 & 9073045.41 & Aureum & 19 & 80 & Ya \\
\hline 9 & 238609.17 & 9072513.79 & Nypa & 91 & 80 & Tidak \\
\hline 10 & 238705.97 & 9072090.86 & Bruguiera & 28 & 80 & Ya \\
\hline 11 & 238384.92 & 9071109.35 & Rhizophora & 14 & 80 & Ya \\
\hline 12 & 238362.97 & 9070921.99 & Rhizophora & 516 & 80 & Tidak \\
\hline 13 & 238133.95 & 9070861.09 & Rhizophora & 97 & 80 & Tidak \\
\hline
\end{tabular}

Keterangan: Baku Mutu untuk Biota Laut (Mangrove) berdasarkan Keputusan Menteri Negara Lingkungan Hidup no.51 Tahun 2004

Menurut Onrizal (2005) vegetasi mangrove merupakan tumbuhan resisten terhadap garam (salt-resistant plants) mampu memelihara pertumbuhannya dalam kondisi cekaman osmotik. Salinitas mempengaruhi penzonasian mangrove melalui perbedaan perakaran setiap spesiesnya. Walupun kondisi salinitas di lokasi penelitian antara 1-22 ppt, mangrove dapat tumbuh baik dilokasi tersebut terutama jenis Rhizophora yang mendominasi.

Salinitas akan terus meningkat nilainya dari muara ke arah laut. Wilayah perairan estuaria daerah tropis dikenal tinggi produktivitasnya karena mempunyai kandungan zat hara yang tinggi dalam air pori (Patriquin, 1992). Hasil pengamatan salinitas pada 13 titik pengamatan yang diambil pada saat pasang menujukkan nilai salinitas mempunyai nilai berkisar antara 1-2 ppt. Rendahnya nilai salinitas diduga dipengaruhi adanya musim penghujan yang mana lebih banyak mendapat asupan dari air hujan daripada air laut. Nilai salinitas dilokasi penelitian sesuai dengan baku mutu air laut menurut kepmen LH No.51 tahun 2004 yaitu nilai salinitas ideal untuk mangrove sampai dengan 34 ppt dan diperbolehkan terjadi perubahan sampai dengan $<5$ ppt salinitas rata-rata musiman

Tabel 4. Data Salinitas Hasil Penelitian di Estuari Perancak pada saat pasang dibandingkan terhadap Baku Mutu untuk Biota Laut

\begin{tabular}{|c|c|c|c|c|c|c|}
\hline \multirow{2}{*}{$\begin{array}{l}\text { Nama } \\
\text { Titik }\end{array}$} & \multicolumn{2}{|c|}{ Koordinat } & \multirow{2}{*}{$\begin{array}{c}\text { Jenis } \\
\text { mangrove } \\
\text { dominan }\end{array}$} & \multirow{2}{*}{$\begin{array}{c}\text { Salinitas } \\
\text { (ppt) }\end{array}$} & \multirow{2}{*}{$\begin{array}{l}\text { Baku } \\
\text { Mutu }\end{array}$} & \multirow[t]{2}{*}{ Ket } \\
\hline & $x$ & $Y$ & & & & \\
\hline 1 & 239135.65 & 9071372.67 & Rhizophora & 11 & $\mathrm{~s} / \mathrm{d} 34$ & $\mathrm{Ya}$ \\
\hline 2 & 238975.57 & 9071498.66 & Avicennia & 9 & s/d34 & $\mathrm{Ya}$ \\
\hline 3 & 238808.59 & 9071165.75 & Sonneratia & 21 & s/d34 & $\mathrm{Ya}$ \\
\hline 4 & 238761.58 & 9071640.29 & Rhizophora & 20 & $\mathrm{~s} / \mathrm{d} 34$ & $\mathrm{Ya}$ \\
\hline 5 & 238650.19 & 9071927.58 & Rhizophora & 14 & $\mathrm{~s} / \mathrm{d} 34$ & $\mathrm{Ya}$ \\
\hline 6 & 238510.37 & 9071864.08 & Rhizophora & 22 & s/d34 & $\mathrm{Ya}$ \\
\hline 7 & 238678.34 & 9073170.63 & Bruguiera & 1 & $\mathrm{~s} / \mathrm{d} 34$ & $\mathrm{Ya}$ \\
\hline 8 & 238664.67 & 9073045.41 & $\begin{array}{c}\text { Acrostichum } \\
\text { Aureum }\end{array}$ & 1 & $\mathrm{~s} / \mathrm{d} 34$ & Ya \\
\hline 9 & 238609.17 & 9072513.79 & Nypa & 12 & $\mathrm{~s} / \mathrm{d} 34$ & Ya \\
\hline 10 & 238705.97 & 9072090.86 & Bruguiera & 10 & $\mathrm{~s} / \mathrm{d} 34$ & $\mathrm{Ya}$ \\
\hline 11 & 238384.92 & 9071109.35 & Rhizophora & 18 & $\mathrm{~s} / \mathrm{d} 34$ & Ya \\
\hline 12 & 238362.97 & 9070921.99 & Rhizophora & 21 & $\mathrm{~s} / \mathrm{d} 34$ & $\mathrm{Ya}$ \\
\hline 13 & 238133.95 & 9070861.09 & Rhizophora & 16 & $\mathrm{~s} / \mathrm{d} 34$ & Ya \\
\hline
\end{tabular}




\section{Hubungan Nilai NDVI dengan Parameter}

Analisis korelasi bertujuan untuk mengukur kekuatan asosiasi (hubungan) linear antara dua variabel. Untuk menentukan korelasi antar variabel menggunakan metode regresi linier kuadratik. Metode regresi linier kuadratik ini digunakan untuk mengetahui hubungan antar variabel yang memiliki banyak parameter.

Tabel 5. Nilai indeks vegetasi dan parameter tahun 2015

\begin{tabular}{|c|c|c|c|c|}
\hline \multirow[b]{2}{*}{$\begin{array}{l}\text { Nama } \\
\text { Titik }\end{array}$} & \multirow{2}{*}{$\begin{array}{c}\text { Jenis } \\
\text { mangrove } \\
\text { dominan }\end{array}$} & \multirow[b]{2}{*}{ NDVI } & \multicolumn{2}{|c|}{ Parameter } \\
\hline & & & $\begin{array}{l}\text { Salinitas } \\
\text { (ppt) }\end{array}$ & $\begin{array}{c}\text { TSS } \\
(\mathrm{mg} / \mathrm{L})\end{array}$ \\
\hline 1 & Rhizophora & 0.641874 & 11 & 29 \\
\hline 2 & Avicennia & 0.260178 & 9 & 8 \\
\hline 3 & Sonneratia & 0.759335 & 21 & 15 \\
\hline 4 & Rhizophora & 0.770907 & 20 & 18 \\
\hline 5 & Rhizophora & 0.831185 & 14 & 20 \\
\hline 6 & Rhizophora & 0.805049 & 22 & 195 \\
\hline 7 & Bruguiera & 0.460387 & 1 & 11 \\
\hline 8 & $\begin{array}{c}\text { Acrostichum } \\
\text { Aureum }\end{array}$ & 0.407634 & 1 & 19 \\
\hline 9 & Nypa & 0.617120 & 12 & 91 \\
\hline 10 & Bruguiera & 0.686399 & 10 & 28 \\
\hline 11 & Rhizophora & 0.833129 & 18 & 14 \\
\hline 12 & Rhizophora & 0.687272 & 21 & 516 \\
\hline 13 & Rhizophora & 0.613140 & 16 & 97 \\
\hline
\end{tabular}

Korelasi hidrologi yang dilihat dari parameter fisik (salinitas dan TSS) dengan persebaran hutan mangrove (NDVI) didapatkan nilai korelasi berturut-turut adalah 0.7658 dan 0.2902 yang artinya korelasi antara NDVI dengan salinitas kuat sedangkan korelasi ndvi dengan nitrat sangat rendah. Jadi jika nilai NDVI tinggi, maka nilai salinitas juga semakin tinggi. Akan tetapi jika nilai NDVI tinggi belum tentu nilai TSS tinggi pula.

Hasil perhitungan dijelaskan dalam bentuk grafik dan dapat dilihat pada gambar 6 dan 7 .

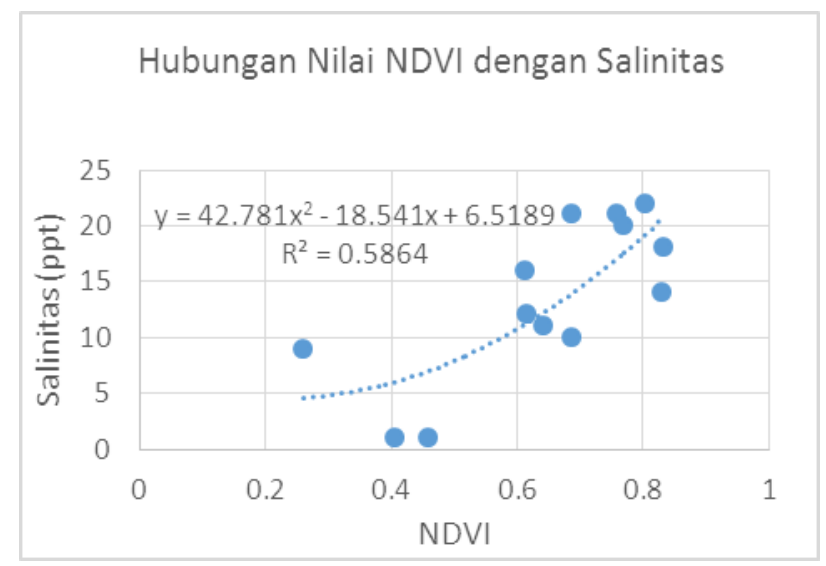

Gambar 6. Grafik hubungan NDVI dengan Salinitas

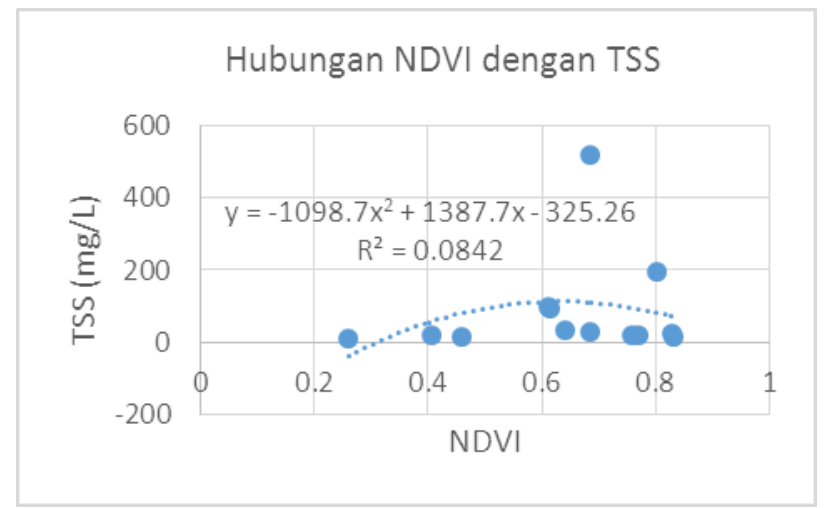

Gambar 7 Grafik hubungan NDVI dengan TSS

Nilai hubungan antara NDVI dengan TSS yang rendah ini dipengaruhi oleh bentuk morfologi hutan mangrove yang dikelilingi oleh sungai tidak berhadapan langsung dengan laut yang mana mendapat hutan mangrove mendapat asupan nutrisi tidak hanya dari air laut tetapi oleh air sungai juga, terlebih lagi pengambilan sampel dilakukan pada saat musim hujan dan pada saat kondisi air laut pasang dipastikan akan mempengaruhi hasil parameter nitrat.

\section{PENUTUP}

\section{Kesimpulan}

Dari hasil penelitian di atas, dapat disimpulkan bahwa Persebaran hutan di Estuari perancak dari tahun 2007 sampai tahun 2015 meningkat. Pola hidrologi di wilayah Estuari Perancak dari tahun 2007 sampai tahun 2015 mengalami perubahan yang tinggi dengan ditemukannya bentukan sedimen-sedimen baru hasil dari sedimentasi yang ditumbuhi vegetasi mangrove. Korelasi hidrologi berdasarkan parameter fisik (salinitas dan TSS) dengan persebaran hutan mangrove berdasarkan nilai NDVI didapatkan nilai $R^{2}$ berturut-turut adalah 0.5864 dan 0.0842 yang artinya korelasi antara NDVI dengan salinitas sedang, korelasi antara NDVI dengan TSS sangat rendah. Sehingga jika nilai NDVI tinggi tidak pasti nilai parameter hidrologi tinggi, dikarenakan letak penelitian yang dikelilingi oleh sungai dan jarak dari bibir pantai sepanjang $3133.45 \mathrm{~m}$. Parameter yang berhubungan erat dengan ndvi yaitu salinitas. 


\section{Saran}

Sebagai saran guna penelitian selanjutnya, untuk perolehan luas hutan mangrove yang lebih baik, pemilihan citra hendaknya yang bebas atau minim dari tutupan awan dan menggunakan citra dengan resolusi spasial lebih tinggi dikarenak akan sangat mempengaruhi terhadap hasil perhitungan. Pengambilan data lapangan sebaiknya memiliki waktu yang tidak terlalu jauh dengan data citra sehingga diperoleh ketelitian hasil yang lebih baik.

\section{UCAPAN TERIMAKASIH}

Penulis mengucapkan terimakasih kepada Balai penelitian dan observasi Laut (BPOL) selaku instansi pebimbing dan pengambilan data lapangan, serta Center of Remote Sensing and Ocean Science (CRESOS) yang telah memberikan data citra satelit guna mendukung keberhasilan penelitian ini.

\section{DAFTAR PUSTAKA}

BROK (Balai Riset dan Observasi Kelautan). 2004. Pengembangan Teknologi Struktur Lunak (Greenbelt) untuk Perlindungan Pantai. Laporan Antara. DKP: Pusat Riset Teknologi Kelautan. Balai Riset dan Observasi Kelautan.

Soenarmo, S.H., (2009), Penginderaan Jauh Dan Pengenalan Sistem Informasi Geografi Untuk Bidang Ilmu Kebumian, Institut Teknologi Bandung (ITB).

Purwadhi, F. dan Hardiyati, S. 2001. Interpretasi Citra Digital. Jakarta: PT. Gramedia Widiasarana Indonesia.

Abidin, H. Z. 2002. Penentuan Posisi dengan GPS dan Aplikasinya. Jakarta: Pradnya Paramitha.

USGS. $2013 . \quad<U R L$ http://Landsat.usgs.gov/band_designatio ns_Landsat_satellites.php>. Dikunjungi tanggal 22 April 2015, jam 12:02.

Latifah N., M. Yusuf, I. B. prasetyawan. 2008. Studi Hidrodinamika dan Kualitas Perairan di Pelabuhan Perikanan Pengambengan Bali. Fakultas Perikanan dan IImu Kelautan, Universitas Diponegoro, Semarang 